\title{
EVALUTION OF READING COMPETENCIES OF STUDENTS IN SPECIAL SCHOOLS
}

\author{
[HODNOTENIE CITANIA ZIAKOV SPECIALNYCH ZAKLADNYCH \\ SKOL]
}

\author{
Monika Sulovska - Veronika Hanuljakova
}

\author{
doi: 10.18355/PG.2017.6.2.7
}

\begin{abstract}
The aim of the research was to analyze the reading skills of students with mild intellectual disability in the region of Žilina. The research sample consisted of 16 participants aged $14-15$ years who were at that time studying in the special primary school. Through the data obtained in the book „Skúšky čítania pre mladší školský vek“ written by Mikulajova and Varyova (in Mikulajová et al., 2012) the research shows problematic aspects of reading not only in the technique and the error- rate reading, but also in the area of reading comprehension.
\end{abstract}

\section{Key words}

reading skills, pupil with mild intellectual disability, reading test

\begin{abstract}
Anotácia
Ciel'om výskumu bola analýza čitatel'ských zručností žiakov s l'ahkým stupňom mentálneho postihnutia v Žilinskom kraji. Výskumná vzorka, ktorá sa podrobila hodnoteniu čítania bolo 16 participantov - žiakov špeciálnych základných škôl vo veku 14.-15. rokov. Prostredníctvom dát získaných pomocou Skúšky čítania pre mladší školský vek od autoriek Mikulajovej a Váryovej (in Mikulajová a kol., 2012) výskum odhal'uje problematické aspekty nielen $\mathrm{v}$ technike a chybovosti čítania žiakov, ale najmä v oblasti porozumenia čítaného textu.
\end{abstract}

\section{Kl’účové slová}

čítacie zručnosti, žiak s l'ahkým stupňom mentálneho postihnutia, skúška čítania

\section{Úvod do problematiky}

Jednou z najdôležitejších schopností, ktorú si človek osvojuje počas školskej dochádzky, je čítanie. Táto schopnost' je predpokladom úspechu v škole, základom pre učenie sa. Podl’a Hadasa (2012) dobrý čitatel’ už počas čítania spracováva informácie, nachádzajúce sa $\mathrm{v}$ texte a po prečítaní textu je schopný povedat' jeho obsah. Aké je však čítanie žiakov s mentálnym postihnutím? Práve táto skupina žiakov má v čítaní určité špecifické problémy. Autori Valenta, Michalík, Lečbych a kol. (2012) vo svojej publikácií uvádzajú, že uvedomelého čítania je schopný len žiak s l'ahkým stupňom mentálneho postihnutia. Podobne autori Švarcová (2000), Bendová a Zikl (2011) a d’alší uvádzajú, že najväčšie t’ažkosti robí týmto žiakom 
čítanie s porozumením a orientácia v dlhšom texte. Čítaním žiakov s l'ahkým stupňom mentálneho postihnutia, úrovňou čiastkových kognitívnych funkcií a čitatel'skou gramotnost'ou sa zaoberala Ďord'ovičová a kol. (2015). Do ich výskumu sa zapojilo 46 žiakov s l'ahkým stupňom mentálneho postihnutia, ktorí boli edukovaní v podmienkach školskej integrácie na základnej škole. Výsledky poukázali, že pre cielenú stimuláciu čitatel'skej kompetencie je nevyhnutné $v$ procese edukácie zámerne rozvíjat' čiastkové kognitívne funkcie. Hlebová a kol. (2015) výskumom zistili, že čítanie žiakov s l'ahkým stupňom mentálneho postihnutia, ktorí boli integrovaní v bežnej základnej škole, je na nižšej úrovni $\mathrm{v}$ edukačnom prostredí ako mimo edukačného prostredia, teda triedy. U žiakov sa vyskytovala vyššia chybovost', nižšia úroveň reprodukcie a porozumenia textu. Vo výskume De Graaf a Van Hove (2015) sa zistilo, že výsledky čítania žiakov s Downovym syndrómom bolo lepšie u tých z nich, ktorí boli edukovaní v nižších ročníkoch v bežných školách.

\section{Ciel' výskumu}

Ciel'om nášho výskumu bolo zhodnotit' čitatel'ské schopnosti a čítanie s porozumením žiakov s l'ahkým stupňom mentálneho postihnutia edukovaných v podmienkach špeciálnych základných škôl v Žilinskom kraji. Na základe stanoveného ciel'a sme si vytýčili čiastkové ciele:

- Na základe počtu správne prečítaných slov za istý časový úsek posúdit' techniku čítania žiakov s l'ahkým stupňom mentálneho postihnutia, ktorí navštevujú 9. ročník špeciálnej základnej školy.

- Zistit' úroveň porozumenia a pochopenia významu čítaného textu u žiakov s l'ahkým stupňom mentálneho postihnutia, ktorí navštevujú 9. ročník špeciálnej základnej školy.

- Zaznamenat' a vyhodnotit' chyby pri čítaní.

- Posúdit' chyby na úrovni slova a na úrovni vety a zároveň ich rozdelit' na dobré chyby a zlé chyby.

\section{Výskumné otázky}

Z uvedeného ciel’a sme si stanovili tieto výskumné otázky:

1. Aká je technika čítania žiakov s l'ahkým stupňom mentálneho postihnutia edukovaných v 9. ročníku špeciálnych základných škôl?

2. Aká je úroveň porozumenia významu čítaného textu žiakov s l'ahkým stupňom mentálneho postihnutia edukovaných v 9 . ročníku špeciálnych základných škôl?

3. Aká je úroveň pochopenia významu čítaného textu žiakov s l'ahkým stupňom mentálneho postihnutia edukovaných $\mathrm{v} 9$. ročníku špeciálnych základných škôl?

4. Aké chyby robia žiaci s l'ahkým stupňom mentálneho postihnutia edukovaní v 9. ročníku špeciálnych základných škôl?

\section{Výskumné metódy}

Vzhl'adom na to, že vo výskume sa zameriavame na hodnotenie čítania žiakov 9. ročníka špeciálnych základných škôl s l'ahkým stupňom mentálneho postihnutia, vybrali sme si metódu na hodnotenie čítania, ktorú 
zhotovili Mikulajová a Váryová (Mikulajová a kol., 2012) pod názvom Skúšky čítania pre mladší školský vek. Už z názvu vyplýva, že je určená pre žiakov prvého stupňa ZŠ. Ked’že na trhu nie je žiadna skúška čítania, ktorá by bola vytvorená pre žiakov s mentálnym postihnutím, rozhodli sme sa pre skúšku čítania práve od Mikulajovej a Váryovej. Na problém diagnostiky čítacích zručností žiakov so špeciálnymi edukačnými potrebami (najmä u nehovoriacich žiakov) upozorňujú vo svojom výskume autori Arnold a Reed (2016).

Skúška čítania od Mikulajovej a Váryovej nám umožňuje analyzovat' a hodnotit' techniku čítania, porozumenie čítanému textu, pochopenie významu čítaného textu a chyby pri čítaní - viac informácií o teste si čitatel' nájde v publikácii (Mikulajová a kol., 2012).

Na tomto mieste si dovol'ujeme uviest' dôležité ukazovatele čítania, ktoré získame na základe použitej metódy:

- Kvantitatívne ukazovatele čítania, teda počet správne prečítaných slov za daný časový úsek, v našom prípade za prvú a za druhú minútu.

- Kvalitatívne ukazovatele čítania, teda počet chýb a analýza chýb pri čítaní

- Porozumenie čítanému textu

- Pochopenie významu čítaného textu

Ďalšiu metódu, ktorú sme využívali bola metóda priameho pozorovania. Ked’že sme výskum realizovali s každým žiakom individuálne, mali sme možnost' pozorovat' žiaka pri čítaní textu Nakupovací pes, všímat' si intonáciu, pohyby pri čítaní, správne či nesprávne sedenie pri čítaní textu.

Výskum sme realizovali v mesiacoch december 2016 - január 2017. Výskumný výber tvorili žiaci 9. ročníka špeciálnych základných škôl s l'ahkým stupňom mentálneho postihnutia. Výskum sa realizoval na troch špeciálnych základných školách - ŠZŠ s MŠ, Jána Vojtaššáka 13 v Žiline, ŠZŠ s MŠ v Kysuckom Novom Meste, Lipová 622 a na ŠZŠ, Hradná 336 v Liptovskom Hrádku. Dostupný výber participantov pozostával zo 16 žiakov

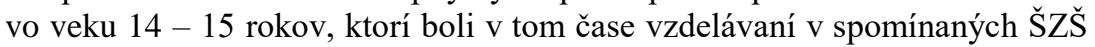
$\mathrm{v}$ A variante. $Z$ toho bolo 10 chlapcov a 6 dievčat. Na 9. ročník sme sa zamerali zámerne, s ciel'om dozvediet' sa, na akej úrovni sa nachádzajú čitatel'ské zručnosti žiakov 9. ročníka, ktorí končia školskú dochádzku na špeciálnych základných školách a budú pokračovat' v d'alšom vzdelávaní, či už na odborných učilištiach alebo praktických školách. Každý učitel' nám pred tým ako sme vykonali skúšku čítania s konkrétnym žiakom, podal pár základných informácií o charaktere žiaka, edukačných výsledkoch v škole, sociálnom prostredí, v ktorom sa nachádza mimo školského času atd'. Pred príchodom žiaka na dané miesto sme ho uvítali a zaznamenali si do hárku jeho meno. Informovali sme žiaka o tom, že jeho úlohou bude prečítat' text, ktorý mu predložíme. Ale zároveň sme ho upozornili aj na fakt, že je potrebné, aby čítal s porozumením, pretože $v$ d'alšej časti nám bude odpovedat' aj na otázky k textu. Ďalšou dôležitou informáciou pre žiaka bolo, 
že text má čítat' bez nadpisu a hned' po tom ako mu ho predložíme. Aby žiaci neboli vystresovaní a vystrašení, oboznámili sme ich aj s faktom, že pre nás nie je prvoradé rýchle čítanie a môže text čítat' svojím tempom, na ktoré je zvyknutý.

Počas čítania sme síce čas žiakovi stopovali, ale tento údaj je pre nás len informatívny. Počas toho ako žiak čítal sme si do textu značili chyby a iné odlišnosti, ktoré sa nám pozdávali byt' dôležité, napríklad intonácia, interpunkčné znamienka, sedenie žiaka pri čítaní, dvojité čítanie, chybné slová, ktoré si však žiak opravil atd'. Sledovali sme aj počet prečítaných slov za prvú minútu a počet prečitaných slov za druhú minútu, na záver sme zaznamenali aj celkový čas, za ktorý žiak text prečítal. Ďalej nasledovala skúška porozumenia čítanému textu, kedy sme pred žiaka predložili 6 otázok $\mathrm{k}$ textu, ktoré sme mu zároveň aj prečítali. V prípade, že by sme otázky nečítali a žiaci by si ich čítali samostatne, mohlo by sa stat, že na základe chýb pri prečítaní otázky, by mohlo dôjst' $\mathrm{k}$ mylnému pochopeniu otázky a zároveň $\mathrm{k}$ chybnej odpovedi. Preto sme považovali za dôležité prečítat' žiakovi otázky, na ktoré nám následne odpovedal. Žiak otázky pred sebou videl a mohol si ich znenie aj skontrolovat'. Pri každej otázke mal na výber $\mathrm{z}$ troch možností. Žiakovu odpoved' sme zaznamenávali do testovacieho hárku. Poslednou častou bola skúška pochopenia významu čítaného textu „Nakupovací pes“, v ktorej sme položili žiakovi 3 otázky. Úlohou žiaka bolo na danú otázku odpovedat' a svoju odpoved' aj odôvodnit'. Do hárku sme zaznamenávali presné znenie odpovede a aj odôvodnenie odpovede.

Po uskutočnení skúšky čítania so všetkými žiakmi a zozbieraní všetkých potrebných materiálov sme u každého žiaka vyhodnocovali :

- Počet slov prečítaných za prvú minútu (priemerná hodnota získaná zo záznamov od výskumníka a pedagóga)

- Počet slov prečítaných za druhú minútu (priemerná hodnota získaná zo záznamov od výskumníka a pedagóga)

- Priemerný počet slov za 1 minútu

- Celkový čas, za ktorý žiak prečítal celý text

- Celkové skóre pri skúške porozumenia čítanému textu

- Počet správnych odpovedí a celkové skóre pri skúške pochopenia významu čítaného textu

- Analýza chýb pri čítaní - počet všetkých chýb na úrovni slova a počet všetkých chýb na úrovni vety, z toho sme počítali „Dobré chyby“ a „Zlé chyby“.

Záznamový hárok Analýza chýb pri čítaní textu „Nakupovací pes“ sme previedli do príslušných grafov, kde uvádzame aj kategórie chýb, musíme však podotknút, že do počtu chýb sme zarad'ovali všetky chyby získané zo záznamov od výskumníka a pedagóga, ktorí sa zúčastnili na výskume a hodnotení čítania.

Autorky Mikulajová a Váryová (in Mikulajová a kol., 2012) uvádzajú kategórie chýb na úrovni slova a na úrovni vety. 
Chyby na úrovni slova:

- Gramatická zmena, ide o chybu, kde pôvodné slovo je prečítané len $\mathrm{s}$ inou príponou. Príklady : z tried $-\mathrm{z}$ triedy...

- Sémanticky blízke slovo, chyby je významom blízke slovo, väčšinou odvodené. Príklady : slnce - slniečko...

- Sémanticky vzdialené slovo, chybné slovo je významom vzdialené pôvodnému slovu, často má podobnú fonologickú štruktúru. Príklady : spáva - správa...

- Pridanie slova, chyba vznikne pridaním slova, ktoré v texte nie je.

- Vynechanie slova, chyba vznikne neprečítaním slova, dochádza $\mathrm{k}$ vynechaniu slova $\mathrm{z}$ textu.

- Zámena funkčného slova, chyba vznikne zámenou slova z textu za iné slovo. Týka sa to výlučne funkčných slov, ako sú predložky, častice, spojky, citoslovcia. Príklady : ach - aha...

- Pseudoslovo, chyba vznikne, ak prečítaním slova z textu vznikne umelé slovo, ktoré sa nenachádza v slovníku slovenského jazyka. Ide o neexistujúci tvar, nejde o nezvyčajný tvar pri ohýbaní slov. pseudoslová tvoria výnimku v tom, že ich neposudzujeme na úrovni vety. Príklady : vhupol - vhutil...

Chyby na úrovni vety (každú chybu po zaradení do kategórie na úrovni slova posudzujeme $\mathrm{v}$ kontexte vety $\mathrm{z}$ hl'adiska gramatickej a sémantickej správnosti).

Gramatická stránka :

- Chyba nenaruší gramatickú správnost' vety (gram +), chybné slovo posudzujeme v kontexte vety, nenaruší syntax vety. V súvetiach chybu posudzujeme v súlade s okolitými slovami.

- Chyba naruší gramatickú správnost' vety (gram -), príklad: Asi nie je piatok, lebo (namiesto ale) sobota.

Sémantická stránka :

- Chyba nenaruší význam vety (sem +), príklad: Nuž čože by si (pridané) robil?

- Chyba naruší význam vety (sem -), príklad : už (namiesto až) sa zobudil .

Váryová a Mikulajová (in Mikulajová a kol., 2012, s. 150) navrhujú delit' chyby na :

- tzv. dobré chyby - sem patria chyby na úrovni slov : gramatické zmeny a sémanticky blízke slová. $\mathrm{Na}$ úrovni viet tieto „dobré chyby“ nenarušia gramatickú ani významovú stránku vety.

- tzv. zlé chyby na úrovni slov sú sémanticky vzdialené slová a pseudoslová. Na úrovni vety tieto ,zlé chyby“ narušia gramatickú a významovú stránku vety.

\section{Diskusia}


Analýza čítania žiakov priniesla odpovede na výskumné otázky, ktoré uvádzame v nasledujúcom texte.

\section{Aká je technika čítania žiakov s l'ahkým stupňom mentálneho} postihnutia edukovaných v 9. ročníku špeciálnych základných škôl?

Pri pedagogickej diagnostike rozoznávame rôzne techniky čítania, napríklad technika čítania hláskovaním, žiak slabikuje, globálna technika čítania alebo žiak číta kombinovane. V našom prípade sa u 5 participantov objavilo dvojité čítanie slabikovaním, kedy žiak najskôr číta slabiky potichu a potom ich prečíta nahlas. Táto technika však u participantov nepretrvávala do konca čítaného textu. Technika dvojitého čítania slabikovaním sa u žiakov objavovala predovšetkým pri čítaní dlhších alebo komplikovanejších slov, ktoré mnohokrát aj tak prečítali zle a vytvorili zo slova pseudoslovo. Môžeme teda konštatovat', že technika dvojitého čítania slabikovaním sa u žiakov prejavovala len čiastočne. Z celkového počtu všetkých participantov, 11 participanti používali na čítanie globálnu techniku čítania. To znamená, že žiak číta text hned' nahlas. Technika globálneho čítania teda prevládala a môžeme konštatovat', že u žiakov s l'ahkým stupňom mentálneho postihnutia edukovaných v 9. ročníku špeciálnych základných škôl prevláda globálna technika čítania. U jedného participanta sa vyskytlo používanie palca počas celého čítania, ktorým si ukazoval čítaný text.

2. Aká je úroveň porozumenia významu čítaného textu žiakov s l'ahkým stupňom mentálneho postihnutia edukovaných v9. ročníku špeciálnych základných škôl?

Žiaci boli viac úspešní v skúške porozumenia čítanému textu, kde odpovedali na otázky a vyberali si $\mathrm{z}$ troch odpovedí. Otázky s možnost'ou výberu správnej odpovede žiakom s l’ahkým stupňom mentálneho postihnutia vyhovujú, pretože žiaci majú na výber a zároveň za správnu odpoved' často označia slová a odpovede, ktoré sa nachádzajú v texte. Nemusia tvorit’ žiadne vety či vlastné odpovede.

$\mathrm{Na}$ základe získaných hodnôt môžeme konštatovat', že žiaci získali v priemere 4 body zo 6 v skúške porozumenia čítanému textu. To znamená, že percentuálna úspešnost' v skúške porozumenia čítanému textu bola $67 \%$.

3. Aká je úroven̆ pochopenia významu čítanému textu žiakov s l’ahkým stupňom mentálneho postihnutia edukovaných v9. ročníku špeciálnych základných škôl?

Participanti mali značné problémy v skúške pochopenia významu čítaného textu. Skúška pochopenia významu čítaného textu slúži predovšetkým na odhalenie faktu, či žiak dokáže postrehnút' dejové súvislosti, aká je jeho slovná zásoba, zároveň vyvodzuje závery, teda $\mathrm{v}$ tomto prípade ide o komplexnejšiu úlohu pre žiakov. Ciel’om skúšky je odhalit' implicitné významy $\mathrm{v}$ širších súvislostiach. V prvej časti skúšky žiaci odpovedali na konkrétnu otázku. V druhej časti skúšky bolo úlohou žiakov odôvodnit' svoju odpoved' a prezentovat' tak vlastné postoje a názory, vlastný spôsob uchopenia súvislostí deja. Žiaci s l'ahkým stupňom mentálneho postihnutia mali s touto čast'ou skúšky vel'ké problémy. Je pre nich t’ažké vyjadrovat' svoj vlastný názor a postoj, ktorý je navyše aj hodnotený a je potrebné, aby vyjadrenie žiaka bolo adekvátne. Vyskytovali sa aj odpovede, ktoré boli výplodom fantázie niektorých žiakov. Nič to však nemení na fakte, že 
odpovede boli nesprávne. Rovnako aj $\mathrm{v}$ tomto prípade sme spriemerovali celkové skóre získané v skúške pochopenia významu čítaného textu. Celkové priemerné skóre $\mathrm{v}$ tejto skúške bolo 2 , to znamená, že žiaci získali v priemere v skúške pochopenia významu čítaného textu 2 body zo 6 bodov. To znamená, že percentuálna úspešnost' žiakov s skúške pochopenia významu čítaného textu je $33 \%$. Je potrebné podotknút, že táto skúška sa skladala z troch otázok a každá otázka mala podotázku. Prvá otázka bola napríklad $a$ ) Kto za to môže, že sa nákup nevydaril? a podotázka bola napríklad b) Prečo si to myslís.s. To znamená, že v podotázke museli žiaci svoju odpoved' odôvodňovat'. Na základe spriemerovania získaných údajov od respondentov sme dospeli $\mathrm{k}$ záverom, že $\mathrm{v}$ prvej otázke získali priemerne 2 body z 3 a v podotázke získali len 1 bod z 3 možných bodov. To znamená, že pri odôvodňovaní svojich odpovedí bola úspešná len jedna tretina všetkých respondentov.

4. Aké chyby robia žiaci s l'ahkým stupňom mentálneho postihnutia edukovaní v 9. ročníku špeciálnych základných škôl?

U respondentov sme zaznamenali chyby, ktoré sa pri čítaní textu vyskytovali najčastejšie. Tieto chyby zarad'ujeme do kategórie: gramatická zmena, pseudoslovo a sémanticky vzdialené slová. Chyby, ktoré zarad'ujeme do kategórie gramatická zmena patria medzi tzv. dobré chyby. Medzi tzv. zlé chyby patria kategórie pseudoslovo a sémanticky vzdialené slová.

Pri gramatických zmenách išlo $\mathrm{v}$ mnohých prípadoch len o drobné zmeny v príponách. Tieto chyby môžu byt' dôsledkom rýchleho čítania žiaka, kedy sa žiak zameriaval predovšetkým na rýchlost'. Počas čítania žiak urobil drobnú chybu na konci slova, chybu zaregistroval, ale v rýchlosti ju neopravil. Často ide o chyby, ktoré nenarúšajú sémantickú čast' vety, teda význam vety býva zachovaný. Inak je to už v prípade tzv. zlých chýb, kedy sa najčastejšie vyskytovali chyby, ktoré zarad'ujeme do kategórie pseudoslov a sémanticky vzdialených slov. Mikulajová a kol. (2012) uvádza, že viac ako štvrtinu z celkového počtu chybne prečítaných slov predstavujú práve slová sémanticky vzdialené od pôvodného slova a pseudoslová. Tieto typy chýb menia význam viet, čím narúšajú porozumenie a pochopenie významu čítaného textu. 


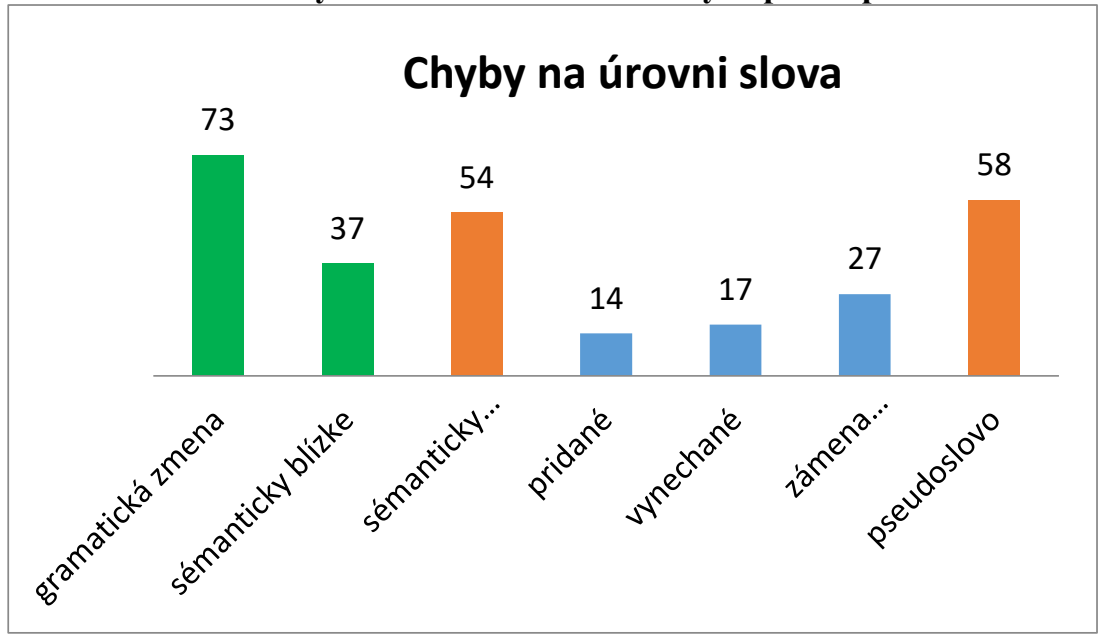

Legenda: zelená farba - dobré chyby, červená farba - zlé chyby, modrá farba - typické chyby slabých čitatel'ov

Z grafu č. 1 vyplýva, že tzv. dobrých chýb bolo 39,3\% a tzv. zlých chýb bolo $40 \%$ z celkového počtu chýb na úrovni slova. Všimnime si, že rozdiel medzi dobrými a zlými chybami je vel'mi malý až zanedbatel'ný. Za dôležitejšie považujeme všimnút' si, ktoré typy chýb sa u žiakov vyskytovali najčastejšie. Medzi najčastejšie sa vyskytujúce chyby zarad'ujeme chyby v kategórií gramatická zmena (odchýlil - odchytil, mido - mydlo...), pseudoslovo (rôzne pseudoslová vznikali pri čítaní slov samoobsluhe, žuvačku, desat'korunáčku, Mrkvičkovi...) a sémanticky vzdialené slová (nevedia - nevidia, cedul’u cibul'u, siahol-stiahol, kocúr-cukor, dávali-divali, zošit-košík, pomyslel - posmieval...). Často sa pri čítaní textu vyskytovali drobné gramatické chyby, napríklad zmeny koncoviek. Mnohé z týchto chýb boli zaradené do kategórie gramatická zmena, teda medzi tzv. dobré chyby (chodil - chodí, bolo - bol...). Ale tento fakt nám môže hovorit' aj to, že žiaci neboli pozorní pri čítaní až do konca daného slova a ponáhl'ali sa prečítat' d'alšie slovo. Toto môže byt' dôsledkom zníženej pozornosti u žiakov s l'ahkým stupňom mentálneho postihnutia.

V grafe č.2, ktorý sa zameriava na chyby na úrovni vety môžeme pozorovat' dve výrazné hodnoty. Prvou hodnotou sú chyby, ktoré nám gramatiku viet nenarušia. Druhou hodnotou sú však chyby, ktoré nám narušia význam viet. $\mathrm{Aj}$ napriek tomu, že $\mathrm{v}$ grafe prevládajú chyby, ktoré gramatiku viet nenarúšajú, tzv. dobré chyby, nemôžeme nespomenút' tzv. zlé chyby, ktoré výrazne narúšajú význam viet. Tzv. dobrých chýb bolo 58,6\% a tzv. zlých chýb bolo $41,4 \%$. 
Graf 2 Frekvencia chýb na úrovni vety u všetkých participantov

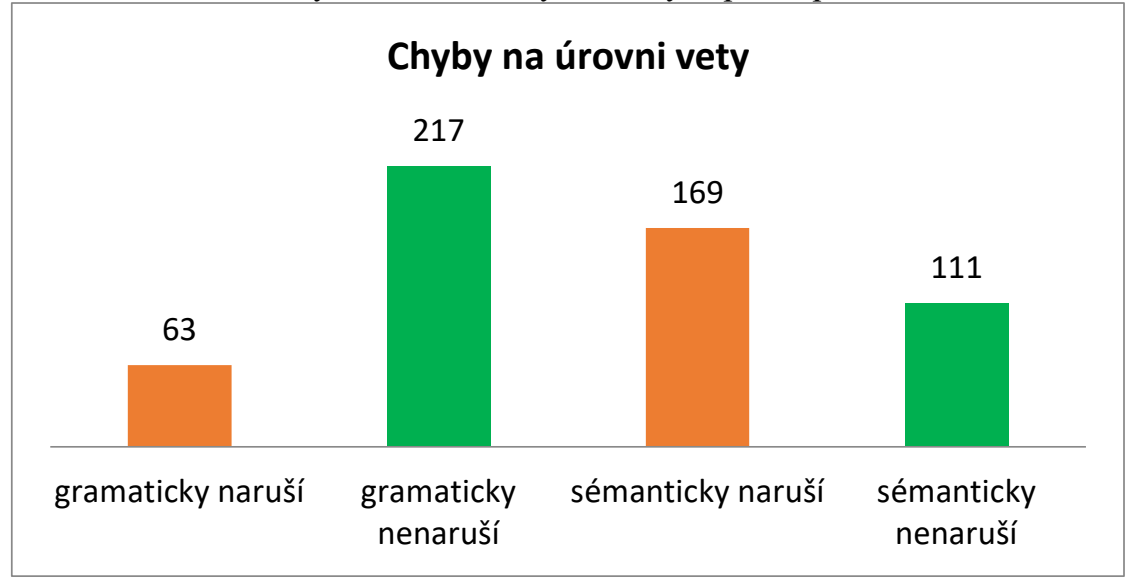

Legenda: zelená farba - dobré chyby, červená farba - zlé chyby Ďalšie hodnoty, ktoré sme získali spriemerovaním údajov získaných od participantov sú :

- Žiak s l’ahkým stupňom mentálneho postihnutia prečíta v priemere za prvú minútu 71,2 slov.

- Žiak s l’ahkým stupňom mentálneho postihnutia prečíta v priemere za druhú minútu 53,9 slov.

- Žiak s l’ahkým stupňom mentálneho postihnutia prečíta $\mathrm{v}$ priemere za jednu minútu 70 slov.

- Priemerný celkový čas, za ktorý žiak prečíta text ( 250 slov) je 4,06 minút, teda 243,6 sekúnd.

- Priemerný počet chýb v celom texte (250 slov) je 17,5 chýb.

Žiaci mali značný problém s porozumením čítaného textu, ale predovšetkým s pochopením významu čítaného textu. Výsledky výskumu potvrdili fakt, na ktorý poukazujú Bendová a Zikl (2011), že u žiakov s mentálnym postihnutím dochádza $\mathrm{k}$ zníženiu porozumenia obsahu textu. To predovšetkým z dôvodu krátkodobej pozornosti žiakov, zníženej schopnosti orientovat' $\mathrm{sa} v \mathrm{v}$ texte, nedostatkov $\mathrm{v}$ oblasti abstraktného vnímania či nedostatkov v oblasti predstavivosti. Rovnako aj Pokorná (2010) zdôrazňuje potrebu krátkodobej pamäte pri čítaní s porozumením, čo je vel'mi náročný proces. Pri č́taní participantov sme mohli pozorovat' aj prejavy ako napríklad domýšlanie slov, neporozumenie významu slova (pri skúške porozumenia a pochopenia významu čítaného textu) či využívanie náhradných techník čítania (dvojité čítanie slabikovaním). Bednářová a Šmardová (2011) uvádzajú, že aj tieto prejavy v čítaní sú dôkazom oslabenia niektorých čiastkových kognitívnych funkcií.

Pri odpovediach na otázky sme mohli pozorovat' jednoduché odpovede, typu neviem, áno, nie, asi áno. Žiaci vôbec nevyužívali možnost' odpovede celou 
vetou. O jednoduchosti komunikácie, využívaním jednoduchých viet a súvetí u žiakov s l'ahkým stupňom mentálneho postihnutia sa zmieňuje Švarcová (2000). Podotýka, že rozvoj reči je u nich v porovnaní s vývinovou normou oneskorený a včítaní a písaní majú špecifické problémy. Zdôrazňuje, že t’ažkosti im robí čítanie s porozumením a orientácia $\mathrm{v}$ dlhšom texte, čo sa potvrdilo aj pri výsledkoch výskumu. Uvedomujeme si, že článok mohol byt' pre niektorých žiakov s l'ahkým stupňom mentálneho postihnutia pridlhý na to, aby boli schopní odpovedat' a zároveň sa aj sústredit' na odpovede. Avšak skúška čítania vytvorená špeciálne pre žiakov s mentálnym postihnutím na trhu absentuje.

Skúška pochopenia významu čítaného textu sa nachádzala na samom konci hodnotenia čítania, takže je viac ako pravdepodobné, že za uplynulý čas žiaka vyrušilo v jeho sústredení mnoho faktorov, či už nervozita, stres, nálada žiaka, prítomnost' výskumníka a rôzne iné faktory, či detaily, ktoré sa mohli nachádzat' v okolí, ale ktoré sme zároveň nevedeli ovplyvnit'.

\section{Záver}

Príspevok bol zameraný na hodnotenie čítania u žiakov s l'ahkým stupňom mentálneho postihnutia edukovaných $\vee$ špeciálnych základných školách $\vee 9$. ročníku. $\mathrm{Na}$ analýzu čítania participantov sme použili najnovší výskumný nástroj na Slovensku - Skúšky čítania pre mladší školský vek od autoriek Mikulajovej a Váryovej z roku 2012. Na základe výsledkov získaných z analýzy záznamových hárkov výskumného nástroja sme mohli sumárne zhodnotit' úroveň čitatel'ských kompetencií žiakov s l'ahkým stupňom mentálneho postihnutia. Zo výsledkov výskumu upozorňujeme na nevyhnutnost' venovat' problematike čítania žiakov s l'ahkým stupňom mentálneho postihnutia značnú pozornost' a vyvodit' tak opatrenia na odstránenie nedostatkov v edukácií čítania. Vzhladom na výberový súbor, získané výsledky nemôžeme zovšeobecňovat' na celú populáciu žiakov s l’ahkým stupňom mentálneho postihnutia na Slovensku. Avšak závery, ku ktorým sme dospeli, považujeme za prínosné pre oblast' špeciálnej didaktiky slovenského jazyka a literatúry, a zároveň inšpirujúce pre d’alšie výskumné zámery.

\section{Bibliographic references}

ARNOLD, S. - REED, P. 2016. Reading assessments for students with ASD: A survey of summative reading assessments used in special educational schools in the UK. British Journal of Special Education, 43(2), pp. 122-141. doi:10.1111/1467-8578.12127.

BEDNAROVA, J. - SMARDOVA, V. 2011. Skolni zralost : co by melo umet dite pred vstupem do skoly. Brno: Computer Press, 2011. ISBN 978-80251-2569-4.

BENDOVA, P. - ZIKL, P. 2011. Dite s mentalnim postizenim ve skole. Praha : Grada Publishing, a. s. ISBN 978-80-247-3854-3.

DE GRAAF, G. - VAN HOVE, G. G. 2015. Learning to read in regular and special schools: A follow-up study of students with down syndrome. Life Span and Disability, 18(1), pp. 7-39. 
DORDOVICOVA (SOPKOVA), J. - HLEBOVA, B. - PALKOVA, V. 2015. Analyza vztahu ciastkovych kognitivnych funkcii a citatelskej gramotnosti ziakov s lahkym stupnom mentalneho postihnutia $v$ skolskej integracii. In Skola jako misto setkavani 2015 aneb Ucime se pro zivot, ne pro skolu. Praha : Univerzita Karlova v Praze, 2015. pp. 10-21. ISBN 978-80-7308-5605.

FELIX, V. G. - MENA, L. J. - OSTOS, R. - MAESTRE, G. E. 2017. A pilot study of the use of emerging computer technologies to improve the effectiveness of reading and writing therapies in children with down syndrome. British Journal of Educational Technology, 48(2), pp. 611-624. doi:10.1111/bjet.12426.

HADAS, K. 2012. Sokat kell gyakorolni. In Uj Szo, 5.1.2012, Vol. 65, N. 4., p. 20.

HLEBOVA, B. - DORDOVICOVA, J. - PALKOVA, V. 2015. Kognitivna stimulacia citatelskej kompetencie ziakov s lahkym stupnom mentalneho postihnutia v skolskej integracii. Presov : Presovska univerzita v Presove, 2015. ISBN 978-80-555-1456-7.

MIKULAJOVA, M. 2009. Jazykovo-kognitivne metody prevencie a terapie dyslexie. Ucebny text pre logopedov, psychologov a specialnych pedagogov. Bratislava : MABAG spol. s r. o. ISBN 978-80-89113-74-3.

MIKULAJOVA, M. a kol. 2012. Citanie, pisanie a dyslexia s testami a normami. Bratislava : MABAG spol. s r. o. ISBN 978-80-89113-94-1.

POKORNA, V. 2010. Vyvojove poruchy uceni v detstvi a dospelosti. Prague: Portal. ISBN 978-80-7367-773-2.

SMITH, S. - ARTHUR-KELLY, M. 2016. Perceptions of differentiating pedagogy for gifted readers, typically developing readers, and students with reading difficulties in multi-grade primary classrooms. Australasian Journal of Gifted Education, 25(2), 52-69. doi:10.21505/ajge.2016.0015.

STADTLER, M. 2017. The art of reading in a knowledge society: Commentary on the special issue on models of multiple text comprehension. Educational Psychologist, 52(3), pp. 225-231. doi:10.1080/00461520.2017.1322969.

VALENTA, M. - MICHALIK, J. - LECBYCH, M. a kol. 2012. Mentalni postizeni $\mathrm{v}$ pedagogickem, psychologickem a socialne-pravnim kontextu. Praha : Grada Publishing, a. s. ISBN 978-80-247-3829-1.

VANCOVA, A. 2005. Zaklady pedagogiky mentalne postihnutych. Bratislava: Sapientia, Bratislava, 2005. ISBN 8096879766.

PaedDr. Monika Šulovská, PhD.

Mgr. Veronika Hanuljaková

Comenius University

Faculty of Education, Department of Special Education

Račianska 59, Bratislava 81334

Slovakia

sulovskamonika@gmail.com 